\title{
Strategi Coping Mahasiswa dalam Menghadapi Perubahan Sistem Perkuliahan di Masa Pandemi COVID-19
}

\section{Students' Strategies for Coping with the Emergency Transition to Online Learning under the COVID-19 Pandemic}

\author{
Nurchayati, Muhammad Syafiq, Riza Noviana Khoirunnisa, Ira Darmawanti \\ Program Studi Psikologi Universitas Negeri Surabaya, Indonesia
}

\begin{abstract}
This study examined two things: a) challenges confronting undergraduate students as a result of an abrupt transition to online learning in response to the COVID-19 pandemic, and b) the coping techniques that they employed to tackle the challenges. Using Google Forms, interviews were conducted with 418 undergraduate students in one of universities in Surabaya. Qualitative thematic analysis of the interviews produced three findings. First, among the problems faced by the students are poorly done online classes, trouble interacting with lecturers and classmates, difficulty in accessing course resources, bad Internet connection, environmental distractions, and chaotic changes in class schedules. Second, as a result, the students suffered from increased stress and poor learning experience. Third, to survive, they employed three major coping techniques: problem-focused, emotion-focused, and appraisal-focused. This study concludes that students, lecturers, parents, and the government employ coping strategies that are both synergistic and antagonistic.
\end{abstract}

Keywords: Coping strategies, COVID-19 pandemic, online learning, students

\begin{abstract}
Abstrak: Riset ini mengkaji tantangan para mahasiswa tingkat sarjana akibat transisi mendadak ke pembelajaran dalam jariringan (daring) di masa pandemi COVID-19, dan strategi mereka dalam mengatasi tantangan itu. Data dikumpulkan melalui wawancara tertulis menggunakan Google Forms terhadap 418 mahasiswa di salah satu perguruan tinggi di Surabaya. Teknik analisis tematik yang digunakan membuahkan tiga temuan. Pertama, masalah-masalah yang dihadapi para sujbek mencakup paparan materi kuliah yang tidak memadai, sukarnya interaksi dengan dosen dan sesama mahasiswa, sukarnya akses ke bahan pembelajaran, buruknya koneksi internet, distraksi lingkungan, dan berubah-ubahnya jadwal kuliah. Kedua, akibatnya, di samping mutu pengalaman belajar para mahasiswa ini menjadi tidak optimal, mereka pun mengalami problem psikis. Ketiga, dalam beradaptasi pada sistem perkuliahan online atau dalam jaringan (daring) dengan berbagai problemnya itu, para mahasiswa menempuh beragam strategi coping yang secara garis besar dapat dikelompokkan ke dalam tiga gugus utama strategi yaitu coping yang berpusat pada problem, coping yang bertumpu pada emosi, dan coping yang berbasis interpretasi. Riset ini mencapai kesimpulan bahwa teknik-teknik coping yang diterapkan oleh berbagai pemangku kepentingan (mahasiswa, dosen, orang tua, dan pemerintah) ternyata bekerja secara sinergis sekaligus antagonistik.
\end{abstract}

Kata kunci: Mahasiswa, pandemi COVID-19, pembelajaran daring, strategi coping

Korespondensi tentang artikel ini dapat dialamatkan kepada Nurchayati melalui email: nurchayati@unesa.ac.id 
Pandemi Corona Virus Desease 2019 (COVID-19) yang mulai merebak sejak bulan Desember 2019 lalu telah mengubah berbagai sendi kehidupan masyarakat di seluruh penjuru dunia. Virus ini mudah menular dan sangat mematikan terutama bagi kelompok-kelompok rentan seperti penderita gangguan pernapasan, jantung, penyakit diabetes, paru-paru, atau kanker. Kondisi ini akhirnya mendorong World Health Organization (WHO) menyerukan kepada masyarakat dunia untuk menerapkan physical distancing, yakni menjaga jarak minimal satu meter dengan individu lain, membersihkan atau mencuci tangan secara teratur, dam menggunakan masker (WHO, 2020).

Masyarakat Indonesia pun tidak luput dari virus mematikan ini. COVID-19 yang mulai menginfeksi Indonesia sejak awal tahun 2020 ini akhirnya memaksa pemerintah dan berbagai elemen masyarakat untuk melakukan perubahan dan berbagai penyesuaian. Pada bidang pendidikan, pemerintah telah mengeluarkan penerapan kebijakan work from home (WFH) dan sistem pembelajaran secara daring (dalam jaringan).

Atas dasar kebijakan pemerintah tersebut, hampir semua perguruan tinggi di Indonesia mengubah proses pembelajaran dari tatap muka langsung atau luring (luar jaringan) menjadi pembelajaran online atau daring (Nugroho, 2020; Patty, 2020). Perubahan sistem perkuliahan secara tibatiba ini menjadi tantangan tersendiri, baik bagi dosen maupun mahasiswa. Dosen terpaksa menyelenggarakan kuliah secara daring (Masriadi, 2020). Perubahan model perkuliahan secara daring ini membuat pembelajaran semakin sulit ketika materimaterinya melibatkan konsep dan rumus kompleks serta melibatkan pengalaman praktik (Firman, 2020; Murdaningsih, 2020). Akibatnya, penyampaian materi menjadi kurang optimal. Para pengajar cenderung mengganti materi dengan tugas, memberikan modul tanpa penjelasan, atau sekadar meminta mahasiswa untuk ber- diskusi secara berkelompok (Amyrah et al., 2020; Iwa, 2020).

Perubahan sistem pembelajaran dari luring ke daring juga menjadi tantangan bagi para mahasiswa. Walaupun sebagian perkuliahan reguler yang berlangsung sebelumnya juga telah menerapkan sistem daring, namun perkuliahan daring selama masa pandemi COVID-19 ini berbeda karena pelaksanaannya sepenuhnya menerapkan sistem daring. Tugas-tugas perkuliahan dan ujian juga sepenuhnya dilaksanakan secara daring. Beragam persoalan pun muncul, mulai dari persoalan teknis dalam mengikuti perkuliahan daring, persoalan akademis, hingga persoalan sosial psikologis.

Secara teknis, banyak mahasiswa mengalami kendala akses jaringan internet (Hutasoit, 2020; Panchanov, 2020). Padahal syarat utama terselenggaranya perkuliahan daring adalah ketersediaan jaringan internet memadai. Sayangnya, tidak semua mahasiswa Indonesia-yang hidup tinggal tersebar di berbagai wilayah Indonesiamemiliki akses internet memadai.

Persoalan akademik juga dialami oleh mahasiswa. Kualitas pembelajaran yang menurun mengakibatkan buruknya pemahaman mahasiswa akan materi perkuliahan (Iwa, 2020; Panchanov, 2020). Selain itu, tugas yang dibebankan pada mahasiswa juga dirasakan lebih berat dari perkuliahan di masa normal akibat dosen seringkali mengganti penyampaian materi dengan pemberian tugas-tugas.

Tidaklah mengherankan bila banyak riset terkait pembelajaran daring selama pandemi lebih berfokus pada masalahmasalah psikologis yang dihadapi siswa atau mahasiswa. Riset-riset itu membuktikan bahwa pembelajaran daring telah mengakibatkan banyak masalah psikologis seperti kecemasan, stres, dan kejenuhan (Lubis \& Rasyid 2021; Andiarna \& Kusumawati, 2020; Harahap et al., 2020; Livana et al., 2020).

Berangkat dari kondisi seperti diuraikan di atas, perlu dilakukan kajian lebih lanjut tentang cara-cara mahasiswa dalam 
menyesuaikan diri dengan berbagai perubahan yang terjadi selama masa pandemi, utamanya perubahan pembelajaran secara daring.

Dalam psikologi, penyesuaian diri didefinisikan sebagai perilaku coping dan proses psikologis yang memungkinkan individu untuk mengelola dan mengatasi tantangan yang dijumpai dalam kehidupan sehari-hari (Nevid \& Rathus, 2016; Santrock, 2006; Weiten et al., 2015). Dalam proses penyesuaian diri ini, seseorang mengalami pertumbuhan yang melibatkan belajar, kemampuan melakukan coping secara efektif, kesediaan menerima tantangan, dan pengembangan kesadaran (Santrock, 2006).

Kemampuan penyesuaian diri pada mahasiswa di perguruan tinggi adalah penting untuk pencapaian prestasi akademik dan persiapan karir di masa depan. Berbagai teknik coping yang digunakan individu dapat bersifat konstruktif maupun maladaptif. Berbagai teknik coping yang konstruktif dapat diklasifikasikan dalam tiga rumpun strategi coping: 1) emotionfocused coping, yang bersandar pada pengelolaan emosi; 2) appraisal-focused coping, yang bertumpu pada penggunaan kerangka interpretasi positif untuk memodifikasi dampak psikis dari stressor yang dialami; dan 3) problem-focused coping, yang mencakup pengerahan berbagai tindakan konkret dalam rangka memecahkan masalah (Weiten et al., 2018).

Berdasarkan kondisi di atas, dapat diketahui bahwa perubahan sistem perkuliahan dari sistem reguler menjadi daring merupakan suatu kondisi yang harus dihadapi oleh mahasiswa dan mereka harus bisa menyesuaikan diri dengan perubahan tersebut. Ketidakmampuan menyesuaikan diri dapat menimbulkan stres dan masalah psikis lainnya. Karena itu, penelitian ini bertujuan untuk mengetahui penyesuaian diri mahasiswa dalam menghadapi perubahan sistem perkuliahan di masa pandemi.

Penelitian ini diharapkan dapat memetakan beragam cara yang dilakukan ma- hasiswa dalam menyesuaikan diri dengan perubahan pembelajaran masa pandemi COVID-19; serta dapat menggambarkan cara-cara penyesuaian diri mahasiswa yang efektif diterapkan di masa darurat.

\section{Metode}

Penelitian ini menggunakan pendekatan kualitatif dengan metode studi kasus. Studi kasus merupakan suatu penelitian empiris yang menyelidiki fenomena dalam konteks kehidupan nyata bilamana batasbatas antara fenomena dengan konteks tidak tampak dengan tegas, dan multisumber data digunakan (Yin, 2009). Studi kasus dilakukan ketika peneliti melakukan eksplorasi terhadap entitas atau fenomena tunggal (the case) yang dibatasi oleh waktu, aktivitas dan pengumpulan detail informasi dengan menggunakan berbagai prosedur pengumpulan data selama waktu tersebut (Cresswell, 2014).

Metode studi kasus ini dipilih karena dua alasan. Pertama, studi kasus bertujuan untuk memastikan, mengkonfirmasi, dan mengembangkan suatu penjelasan teoretis atas suatu "kasus" dalam konteks tertentu (Yin, 2009). Kedua, karena adanya keunikan dalam kasus yang ingin diteliti. Keunikan ini melekat dalam diri subjek penelitian ini sendiri dan konteks terjadinya kasus, yaitu penyesuaian mahasiswa dalam perkuliahan daring selama masa pandemi COVID-19. Keunikannya terletak pada bagaimana pikiran, perasaan, dan tindakan subjek penelitian ketika menjalani perkuliahan daring saat pandemi COVID19 berbeda dengan pilihan tindakan yang mereka ambil saat perkuliahan tatap muka selama situasi normal.

\section{Partisipan}

Penelitian ini dilakukan pada mahasiswa di sebuah program studi di salah satu perguruan tinggi di Surabaya tahun angkatan 2017, 2018, dan 2019. Alasan mereka dipilih menjadi responden penelitian ini adalah karena mahasiswa angkatan 
tersebut merupakan mahasiswa aktif yang memprogram seluruh mata kuliah paket dalam kurikulum. Tabel 1 menampilkan rincian responden penelitian ini:

Tabel 1. Proporsi Responden dibanding Jumlah Mahasiswa Registrasi

\begin{tabular}{cccc}
\hline $\begin{array}{c}\text { Ang- } \\
\text { katan }\end{array}$ & $\begin{array}{c}\text { Jumlah } \\
\text { Mahasiswa }\end{array}$ & $\begin{array}{c}\text { Responden } \\
\text { Penelitian }\end{array}$ & $\begin{array}{c}\text { Persen- } \\
\text { tase }\end{array}$ \\
\hline 2017 & 188 & 165 & $87,76 \%$ \\
2018 & 184 & 80 & $43,48 \%$ \\
2019 & 205 & 172 & $83,90 \%$ \\
\hline Total & 577 & 418 & $72,44 \%$ \\
\hline
\end{tabular}

\section{Pengumpulan Data}

Teknik pengumpulan data penelitian ini adalah wawancara. Karena kondisi pandemi yang tidak memungkinkan dilakukannya wawancara tatap muka, wawancara dilakukan melalui pertanyaan tertulis yang diedarkan dalam bentuk google form. Daftar pertanyaan wawancara yang diajukan adalah pertanyaan tertutup dan terbuka. Pertanyaan dengan format tertutup berguna untuk penelitian yang melibatkan subjek dalam jumlah besar karena memungkinkan untuk mendapatkan respon jawaban yang relatif cepat. Namun jenis pertanyaan ini menyebabkan subjek kurang dapat memberikan respon jawaban di luar alternatif pilihan jawaban yang diberikan (Neuman, 2014; Walliman, 2011).

Untuk menutup kelemahan ini, peneliti mengajukan pertanyaan terbuka yang memberikan kebebasan pada subjek untuk merespon dengan jawaban panjang atau pun pendek atas pertanyaan yang diberikan (Neuman, 2014; Cresswell, 2012). Contoh pertanyaan tertutup dan terbuka dalam penelitian ini: "Pernahkah Anda merasa kewalahan mengikuti perkuliahan daring selama masa pandemi di semester genap 2019-2020 lalu?" (Jawab: selalu, sering, kadang-kadang, hampir tidak pernah, tidak pernah). Apa yang menyebabkan Anda merasa kewalahan dalam mengikuti perkuliahan daring tersebut?

\section{Analisis Data}

Untuk menganalisis data, penelitian ini menggunakan teknik analisis tematik. Analisis tematik dilakukan dengan cara "mengidentifikasi, menganalisis, dan melaporkan pola-pola tema dalam data" (Braun \& Clarke, 2006: 79). Sebuah tema dapat "mencakup sesuatu yang penting dalam data yang terkait dengan 'fokus penelitian' dan menggambarkan makna tertentu dalam data" (Braun \& Clarke, 2006: 82). Analisis tematik dipilih karena "menyediakan alat analisis yang fleksibel yang berpotensi dapat memberikan data yang kaya dan detail" (Braun \& Clarke, 2006: 78). Teknik ini memungkinkan peneliti menggunakan teori untuk mendapatkan pemahaman atas data secara lebih mendalam.

Untuk uji keabsahan data, peneliti melakukan refleksi terhadap proses penelitian yang dijalani untuk mengklarifikasi biasbias yang mungkin dibawa peneliti ke dalam penelitian. Bersama dengan sejawat peneliti, dilakukan evaluasi atas interpretasi data dan prosedur penelitian yang telah ditempuh untuk meningkatkan keakuratan hasil penelitian.

\section{Hasil}

Penelitian ini berhasil mengindentifikasi tiga tema utama yang mencakup beberapa subtema. Temuan tema dan subtema terangkum dalam Tabel 1 yang selanjutnya diuraikan satu persatu.

\section{Persoalan Kuliah Selama Masa Pandemi}

Di masa pandemi, perkuliahan tatap muka tidak dapat diterapkan. Karena itu, kegiatan belajar-mengajar beralih dari sistem luring ke sistem daring. Perubahan ini mengakibatkan berbagai persoalan, baik bagi dosen maupun mahasiswa. Dosen harus menyiapkan materi perkuliahan yang sesuai untuk pembelaljaran secara daring yang tentunya berbeda dengan persiapan perkuliahan secara luring. 
Tabel 1. Kategorisasi Temuan Penelitian

\begin{tabular}{lc}
\hline \multicolumn{1}{c}{ Tema } & Subtema \\
\hline & Paparan materi kuliah tidak memadai \\
$\begin{array}{l}\text { Persoalan kuliah selama } \\
\text { masa pandemi }\end{array}$ & $\begin{array}{c}\text { Keterbatan akses dan interaksi dengan dosen dan teman sekelas } \\
\text { Gangguan belajar dan distraksi lingkungan } \\
\text { Keterbatasan akses pada sumber daya pendukung belajar } \\
\text { Masalah jaringan } \\
\text { Perubahan jadwal kuliah } \\
\text { Persoalan psikis } \\
\text { Dampak yang dirasakan } \\
\text { Pembelajaran tidak optimal } \\
\text { Mencari jaringan internet reliabel } \\
\text { Memperbaiki manajemen waktu } \\
\text { Penyesuaian diri dengan } \\
\text { sistem perkuliahan } \\
\text { daring selama pandemi }\end{array}$ \\
Mencari kekurangan materi dan alat penunjang kuliah \\
Bernegosiasi dengan dosen tentang jadwal perkuliahan \\
Positive thinking, self-talk dan motivasi diri \\
Rekreasi dan relaksasi \\
Religious coping \\
Syukur \\
Berbagi cerita \\
Modifikasi lingkungan \\
Rasa tanggung jawab \\
Minat dan keingintahuan
\end{tabular}

Pandemi yang terjadi di awal perempat waktu perkuliahan mengakibatkan dosen tidak sepenuhnya siap dengan sistem pembelajaran daring. Pada saat yang sama, platform kuliah daring yang dimiliki pihak universitas sedang mengalami gangguan teknis. Padahal, platform kuliah daring merupakan kunci sukses terlaksananya perkuliahan daring. Akibatnya, dosen menggunakan media alternatif untuk menyelenggarakan perkuliahan daring. Dosen juga banyak menggunakan media semacam Whatsapp group untuk berkomunikasi dengan mahasiswa serta memanfaatkan platform lain seperti Google Classroom, Google Meet, Zoom, Google Drive, YouTube, dan Microsoft/Google/Connect Quiz.

Pada mahasiswa, migrasi sistem perkukuliahan dari luring menjadi daring juga menimbulkan persoalan tersendiri. Banyak di antara mereka tidak siap dengan sistem baru karena mereka harus mengubah cara belajar. Hal ini tidaklah mudah sehingga mengakibatkan berbagai masalah. Selain itu, sistem daring juga menuntut mahasiswa agar mampu mengerahkan sumber daya reka miliki agar dapat mengikuti perkuliah-
Tabel 2: Persoalan Mahasiswa dalam Perkuliahan Daring Selama Pandemi

\begin{tabular}{lc}
\hline \multicolumn{1}{c}{ Persoalan Yang Dialami } & $\begin{array}{c}\text { Jumlah } \\
\text { Respon }\end{array}$ \\
\hline $\begin{array}{l}\text { Penjelasan kuliah tidak memadai } \\
\text { Dosen tidak mengisi kuliah pada }\end{array}$ & 233 \\
jam kuliah terjadwal & 101 \\
Jam kuliah terjadwal kosong & 216 \\
$\begin{array}{l}\text { Dosen mengisi kuliah di luar } \\
\text { jam/hari kerja }\end{array}$ & 285 \\
$\begin{array}{l}\text { Dosen memberi tugas dadakan } \\
\text { Beban kuliah tidak wajar }\end{array}$ & 288 \\
Tidak memiliki jaringan internet & 155 \\
yang reliabel & 246 \\
$\begin{array}{l}\text { Anggaran kuota internet } \\
\text { membengkak }\end{array}$ & 244 \\
$\begin{array}{l}\text { Kesulitan koordinasi tugas kelompok } \\
\text { Dosen sulit dihubungi }\end{array}$ & 46 \\
$\begin{array}{l}\text { Dosen tidak merespon pesan } \\
\text { mahasiswa }\end{array}$ & 38 \\
$\begin{array}{l}\text { Komunikasi lebih lambat } \\
\text { Keterbatasan interaksi dan } \\
\text { komunikasi dengan dosen dan teman }\end{array}$ & 78 \\
$\begin{array}{l}\text { Administrasi lebih ribet } \\
\text { Distraksi lingkungan, gangguan dan } \\
\text { masalah belajar }\end{array}$ & 117 \\
\hline
\end{tabular}


an daring. Berdasarkan identifikasi atas respon mahasiswa, diperoleh beragam persoalan perkuliahan yang dihadapi mahasiswa yang dicantumkan dalam Tabel 2 .

Dari sejumlah persoalan yang ditemukan, dapat identifikasi beberapa faktor yang menyebabkan mahasiswa mengalami kesulitan memahami materi perkuliahan selama masa pandemi COVID-19. Berikut dipaparkan beberapa faktor tersebut.

\section{Paparan Materi Kuliah Tidak Memadai}

Dalam menjalani sistem perkuliahan daring di masa pandemi, mahasiswa dituntut mampu menyesuaian diri dengan perubahan sistem perkuliahan dari luring ke daring dan dengan platform pembelajaran berbeda untuk masing-masing dosen. Dalam sistem perkuliahan ini, persoalan besar yang dihadapi mahasiswa adalah paparan materi yang dinilai kurang memadai. Menurut pengalaman mereka, dosen kurang cukup menjelaskan materi, sekedar memberikan Power Point (PPT), atau lebih banyak memberikan tugas:

Materi yang diberikan sebagian besar hanya PPT dan tidak ada penjelasan apapun terkait PPT tersebut (ARD, 29 Juli 2020).

Pemaparan yang didapatkan lebih sedikit dan ruang diskusi yang lebih sedikit dibandingkan pertemuan tatap muka (SNR, 28 Juli 2020).

Pemaparan yang diberikan sedikit. Beberapa mata kuliah mengganti pemaparan dengan tugas sehingga beban tugas dua kali lipat dari biasanya (NLS, 28 Juli 2020).

Banyak dosen mengisi jam perkuliahan dengan memberikan tugas tertulis ataupun presentasi kelas. Sayangnya, tugas tersebut tidak diikuti feedback sehingga mahasiswa tidak mengetahui apakah pemahaman mereka mereka atas materi sudah tepat:

Media pembelajaran yang tidak "tatap muka", sebagian besar disampaikan dengan presentasi mahasiswa. Meskipun beberapa dosen sudah memberikan feedback/tambahan informasi, terdapat dosen yang tidak sama sekali memberikan feedback/tambahan informasi (NSN, 28 Juli 2020).

Karena sering diganti dengan tugas yang tidak ada feedbacknya (EYH, 28 Juli 2020).

Feedback dosen minim, sehingga saya tidak mengetahui apakah pekerjaan saya benar atau salah dan jika salah, di mana letak salahnya (NIS, 29 Juli 2020).

Data di atas menunjukkan bahwa persoalan utama yang dihadapi mahasiswa dalam perkuliahan daring adalah tidak memadainya paparan materi perkuliahan dari para dosen. Umumnya, paparan yang diberikan terlalu singat. Beberapa dosen hanya memberikan materi berupa PowerPoint, mengisi pertemuan kuliah dengan memberikan tugas tanpa umpan balik, dan meminta mahasiswa melakukan presentasi di kelas.

\section{Keterbatasan Akses dan Interaksi dengan Dosen dan Teman Sekelas}

Persoalan kedua yang dihadapi oleh mahasiswa dalam sistem perkuliahan daring adalah keterbatasan akses dan interaksi dengan dosen. Kemajuan teknologi informasi dan internet ternyata tidak serta merta mempermudah komunikasi antar mahasiswa dan dosen. Kondisi ini menjadi salah satu hambatan studi mahasiswa.

Komunikasi antar mahasiswa juga perkuliahan dengan dosen yang lebih sulit (ACO, 29 Juli 2020).

Karena tidak ada komunikasi langsung dengan dosen pengampu perihal konfirmasi materi yang tidak kami mengerti (VLR, 28 Juli 2020).

Sebelum pandemi, para mahasiswa bisa bertatap muka, bertanya, dan melakukan klarifikasi langsung. Namun, pada 
masa pandemi, mereka hanya dapat berkomunikasi melalui alat komunikasi, seperti handphone (HP). Persoalannya, menyampaikan pesan pertanyaan melalui bahasa tulis di HP lebih lambat daripada menyampaikan informasi secara lisan:

Waktu yang digunakan untuk mengetik dan membaca cenderung lebih lama dan terkadang waktu habis untuk mengetik dan membaca (IN, 28 Juli 2020).

Kurangnya waktu untuk memberikan penjelasan, baik dengan mengetik maupun dengan merekam suara (voice note), melakukan tanya-jawab, dan kegiatan lainnya (SES, 28 Juli 2020).

Jadi, persoalan yang dihadapi mahasiswa bukan hanya kesulitan akses komunikasi dengan dosen, tetapi juga keterbatasan waktu mereka untuk mengakses dosen.

Mahasiswa juga kesulitan berkomunikasi dengan teman sekelas, baik untuk membahas persoalan dan materi kuliah atau mengerjakan tugas:

Biasanya saat mendapat kesulitan langsung diskusi dengan teman, sedangkan saat daring sulit untuk melakukan itu (DAZ, 28 Juli 2020).

Saya butuh teman diskusi selama belajar, sedangkan kuliah daring menghambat saya untuk berdiskusi dengan teman-teman (NNFM, 28 Juli 2020).

Berdasarkan uraian di atas, teman sebaya memiliki peran besar dalam proses belajar mahasiswa. Dalam situasi pandemi, akses pada teman sebaya lebih sulit sehingga memperlambat pemahaman mahasiswa atas materi perkuliahan dan dalam melakukan koordinasi tugas perkuliahan.

\section{Gangguan Belajar dan Distraksi}

Persoalan lain yang dihadapi mahasiswa adalah masalah personal seperti kurang dapat memahami materi perkuliahan, sulit fokus pada materi yang diberikan secara daring, menurunnya motivasi, perasaan malas atau malu bertanya. Sejumlah mahasiswa mengalami kesulitan mencerna materi perkuliahan karena sistem perkuliahan daring dirasa tidak cocok dengan gaya belajar mereka selama ini. Hal ini utamanya ketika kuliah disampaikan secara tertulis melalui percakapan Whatsapp:

Saya sendiri lebih mudeng dan nyantol ketika dosen menjelaskan secara langsung (GAW, 28 Juli 2020).

Saya memiliki kemampuan belajar dengan audio di mana saya harus mendengarkan penjelasan. Saya agak kekurangan dalam membaca atau visual sedangkan banyak dosen hanya berkomunikasi melalui WAgrup (NTD, 28 Juli 2020).

Persoalan lain yang dihadapi mahasiswa saat mengikuti perkuliahan sistem daring adalah distraksi lingkungan yang mengakibatkan mereka mengalami kesulitan untuk memahami materi perkuliahan. Kuliah sistem daring memang memiliki beberapa keunggulan, seperti fleksibilitas waktu dan tempat. Namun, sistem ini juga memiliki kelemahan. Fleksibilitas lokasi untuk mengikuti perkuliahan tidak selamanya menguntungkan pembelajar. Dalam sistem perkuliahan luring, perkuliahan dilaksanakan di tempat yang telah dirancang untuk pembelajaran tanpa harus memikirkan persoalan jaringan serta lebih sedikit distraksi. Dalam perkuliahan daring, mahasiswa mengikuti perkuliahan di tempat yang memungkinkan mereka dapat mengikuti perkuliahan dengan lancar, yakni di lokasi atau titik dengan akses jaringan internet memadai. Meskipun berada di lingkungan rumah, lokasi "ramah sinyal" tersebut belum tentu nyaman untuk belajar dan mahasiswa justru merasakan distraksi dalam proses pembelajaran:

Ada terlalu banyak distraksi, baik dari diri sendiri (godaan untuk membuka aplikasi lain di HP) maupun lingkungan (orang tua dan saudara) (LDI, 28 Juli 2020). 
Kondisi lingkungan rumah yang kurang memadai untuk belajar dikarenakan tetangga memiliki usaha bengkel, jadi selalu bising (AUN, 28 Juli 2020).

Cuplikan data di atas menunjukkan bahwa keleluasaan tempat mengikuti perkuliahan daring tidak selalu berdampak positif pada proses pembelajaran. Rumah yang justru merupakan tempat paling nyaman bagi mahasiswa untuk hidup dan tinggal ternyata tidak memberikan suasana kondusif untuk belajar.

Paparan materi yang kurang memadai, kesulitan dalam memahami materi perkuliahan, pola perkuliahan yang lebih banyak memberikan penugasan, dan berbagai persoalan teknis dalam perkuliahan daring ini mengakibatkan mahasiswa mencurahkan waktu lebih banyak untuk belajar dan mempersiapkan diri ketika mengikuti perkuliahan daring. Dari 418 subjek penelitian ini, 274 di antaranya menyatakan bahwa mereka meluangkan waktu lebih lama untuk belajar pada saat ini dibanding sebelum pandemi.

\section{Keterbatasan Akses Pendukung Belajar}

Salah satu persoalan yang dihadapi mahasiswa selama perkuliahan daring adalah kesulitan mengakses sumber daya pendukung belajar, terutama buku perkuliahan. Bila selama perkuliahan luring mereka dapat membaca buku-buku tersebut di perpustakaan atau ruang baca, mereka tidak dapat melakukan hal tersebut karena dua hal: pertama, mereka tinggal di lokasi yang jauh dari kampus. Kedua, tidak semua layanan kampus buka setiap hari:

Biasanya, saat saya di kampus, saya akan pergi ke ruang baca untuk meminjam bahan bacaan. Namun, saat kuliah daring bahan bacaan terbatas (SS, 28 Juli 2020).

Kurangnya bahan ajar yang bisa kita akses (AF, 28 Juli 2020).

Akibat keterbatasan akses ini, penguasaan mahasiswa atas materi kuliah menjadi tidak optimal.

\section{Masalah Jaringan}

Jaringan internet merupakan persoalan umum yang dihadapi oleh para mahasiswa. Walau sebagian besar mahasiswa tinggal di kampung halaman yang terjangkau jaringan internet, mereka juga mengeluhkan kualitas jaringan yang buruk sehingga menghambat proses pembelajaran:

Terkadang jaringan internet yang tidak mendukung menyulitkan untuk mencari referensi materi (PA, 28 Juli 2020).

Suara tidak jelas karena jaringan jelek (DAW, 28 Juli 2020).

Kesulitan ketika memakai aplikasi tertentu untuk kuliah daring karena sinyal internet putus-putus sehingga materi yang diberikan tidak jelas (SWK, 28 Juli 2020).

Karena tidak memadainya jaringan internet di tempat tinggalnya, beberapa mahasiswa terpaksa mengikuti perkuliahan di tempat umum yang menyediakan Wi-Fi. Kondisi ini membuat mahasiswa berada dalam situasi rawan tertular COVID-19.

Paparan di atas mengisyaratkan bahwa persoalan jaringan dalam mengakses perkuliahan tidak bisa dianggap sepele. Kesulitan jaringan tidak hanya mengakibatkan mahasiswa mengalami hambatan dalam mengikuti perkuliahan daring, namun juga dapat menempatkan mereka dalam situasi beresiko tertular COVID-19.

\section{Perubahan Jadwal Kuliah}

Persoalan lain yang dihadapi mahasiswa dalam mengikuti perkulihan daring adalah pergantian jadwal kuliah secara sepihak dan mendadak oleh dosen. Bukan saja berbenturan dengan jadwal kuliah lain, perubahan jadwal ini tak jarang juga dilakukan di luar jam dan hari kerja:

Beberapa dosen mengganti jadwal mata kuliah di hari libur, jadi mau tidak mau saya harus mengikuti mata kuliah tersebut (AK, 28 Juli 2020). 
Tugas yang diberikan dosen tidak sesuai dengan jam resmi mata kuliah dan beberapa deadline bersamaan dan terlalu singkat. Ada juga beberapa mata kuliah berganti jam pertemuan secara mendadak (SNAH, 28 Juli 2020).

Pergantian jadwal ini menimbulkan ketidaknyamanan dan bahkan merusak jadwal yang telah disusun oleh mahasiswa. Perubahan-perubahan terkait pembelajaran semacam ini menimbulkan kecemasan tinggi pada sebagian mahasiswa. Pada gilirannya, hal ini dapat mengganggu kesehatan psikis mereka.

\section{Dampak Yang Dirasakan}

Hampir semua mahasiswa yang menjadi responden penelitian ini merasa kewalahan mengikuti perkuliahan daring selama masa pandemi. Dari 418 responden, hanya 2 orang yang tidak pernah merasa kewalahan dan 11 orang hampir tidak pernah merasa kewalahan. Tidaklah mengherankan jika 278 dari 418 partisipan menyatakan tidak dapat menikmati model perkuliahan daring. Akibatnya, pembelajaran menjadi tidak optimal dan mahasiswa pun rawan mengalami kerentanan psikis seperti stres. Padahal, kesejahteraan psikis sangat diperlukan untuk menjaga kekebalan tubuh mahasiswa agar dapat bertahan menghadapi bahaya COVID-19.

\section{Persoalan Psikis}

Pembelajaran daring mengakibatkan berbagai masalah psikis. Setelah menjalani Ujian Akhir Semester, ada mahasiswa mengeluh dirinya masih tertekan setelah menjalani proses perkuliahan daring. Masalah tersebut muncul karena model pelaksanaan perkuliahan itu sendiri beserta beragam masalah teknis yang menyertainya, seperti masalah listrik, jaringan internet, gawai, dan juga perubahan jadwal pelaksanaan kuliah:

Perkuliahan daring membutuhkan banyak persiapan seperti mempersiapkan materi secara online berupa video.
Jaringan sinyal yang tidak menentu, pemakaian kuota menjadi lebih banyak, dan beban tugas yang semakin banyak sering membuat cemas ataupun stres (AT, 28 Juli 2020).

Saya merasa kurang nyaman dan lebih lelah secara psikis. Selama pembelajaran daring, banyak kendala yang saya temukan, mulai dari kurang memahami materi perkuliahan, kendala sinyal/ jaringan, dan kurang memadainya alat elektronik penunjang yang saya miliki (ADA, 29 Juli 2020).

Cemas, khawatir, lelah, terkadang panik juga dan merasa kesal karena jadwal dan tugas mendadak (FAZ, 28 Juli 2020).

Kondisi psikis saya semakin terganggu, tertekan dan cemas setiap kali ada notifikasi HP karena berbagai informasi selama kuliah daring seringkali mendadak. Pada suatu titik saya ingin minum obat penenang karena saya merasa sangat membutuhkannya (DR, 28 Juli 2020).

Pergantian sistem kuliah dan persoalan teknis kuliah mengakibatkan gangguan tidur dan beragam masalah psikis seperti jenuh, demotivasi, kesepian, khawatir, cemas, tertekan, hingga stres di kalangan mahasiswa:

Saya sering merasa burnout dan cemas pada perkuliahan daring semester lalu. Tidak dapat bertemu dengan kawan seperti biasanya membuat saya sedikit merasa kesepian (DA, 28 Juli 2020).

Semakin malas dan tidak termotivasi untuk belajar (NNA, 28 Juli 2020).

Cemas saat kuliah, deg-degan, overthinking takut nilai jelek (DMP, 29 Juli 2020).

Saya merasa sulit tidur, sering merasa cemas (AS, 29 Juli 2020).

Kecemasan dan stres dalam mengikuti perkuliahan daring diperparah oleh faktor internal dan faktor eksternal lainnya. Faktor internal meliputi kondisi personal 
seperti kepribadian dan kemampuan manajemen diri:

Mengalami stres di rumah karena bingung mau mengerjakan apa (DAS, 28 Juli 2020).

Saya merasa jenuh dan terkadang sensitif karena stres banyak pekerjaan (FAZ, 28 Juli 2020).

Faktor eksternal meliputi kondisi lingkungan dan ekonomi keluarga:

Saat pandemi, perekonomian keluarga semakin terpuruk. Ayah di PHK dari pekerjaannya dan usaha yang dikelola ibu jadi sepi. Saya takut semester depan tidak bisa kuliah lagi (DMP, 29 Juli 2020).

Orang rumah yang selalu ribut, orang tua tersandung masalah sehingga ekonomi sehari-hari saja kurang bahkan sering tidak ada. Pandemi menjadikan saya merasa menjadi beban (NTD, 28 Juli 2020).

Jadi, sistem perkuliahan daring selama masa transisi mengakibatkan beragam masalah psikis seperti cemas dan stres yang diperparah oleh kondisi internal dan eksternal masing-masing mahasiswa.

\section{Pembelajaran Tidak Optimal}

Meskipun perkuliahan daring menyita energi cukup besar dibanding perkuliahan luring, namun mahasiswa merasa bahwa hasil yang mereka raih tidak sebagus ketika perkuliahan luring:

Saya merasa kesusahan memahami teori selama perkuliahan daring. Jika saya perkirakan hanya sekitar $68 \%$ saja teori yang saya pahami. Sisanya hanya common sense (FAZ, 28 Juli 2020).

Sayangnya, ilmu yang dapat saya serap lebih sedikit dibanding ketika kelas reguler (DR, 28 Juli 2020).

Perkuliahan di masa pandemi dirasakan tidak efektif oleh mahasiswa akibat ber- bagai keterbatasan sarana dan prasarana serta sistem pengajaran di masa transisi.

\section{Penyesuaian Diri dengan Perkuliahan Daring Selama Pandemi}

Untuk bertahan dalam situasi penuh tantangan di masa pandemi, mahasiswa mengerahkan beragam metode. Berikut ini akan dipaparkan rupa-rupa metode yang dikerahkan mahasiswa untuk mengatasi beragam persoalan yang mereka alami saat menjalani perkuliahan sistem daring.

\section{Mencari Jaringan Internet Reliabel}

Jaringan internet merupakan hal mutlak yang dibutuhkan mahasiswa dalam mengikuti sistem pembelajaran daring. Tanpa jaringan internet, mahasiswa tidak dapat mengikuti perkuliahan. Sayangnya, tidak semua wilayah Indonesia memiliki jaringan internet reliabel sehingga migrasi perkuliahan dari luring ke daring bukanlah hal sederhana, apalagi mengingat perubahan sistem perkuliahan secara tiba-tiba di pekan ke tujuh perkuliahan semester genap 2019-2020.

Agar dapat mengikuti perkuliahan daring dengan baik, mahasiswa mengusahakan beragam cara, mulai dari membeli tambahan kuota, mencari lokasi umum yang menawarkan Wi-Fi gratis, menumpang pada Wi-Fi orang tua atau teman dan bahkan mengganti kartu SIM ponsel dengan provider yang sinyalnya lebih kuat. Cara paling umum yang digunakan oleh mahasiswa untuk mengikuti perkuliahan daring adalah dengan menambah paket kuota internet jaringan pribadi. Cara ini ditempuh oleh 323 partisipan penelitian.

Dalam upaya mengatasi berbagai kendala akses internet, mahasiswa mengerahkan juga beberapa taktik lain, yaitu mengandalkan jaringan Wi-Fi di rumah sendiri (173 partisipan), menebeng jaringan Wi-Fi orang lain (105 partisipan), mengakses fasilitas Wi-Fi di ruang publik (36 partisipan), atau menggunakan beberapa kombinasi dari taktik tersebut, berpindah lokasi 
untuk mendapat sinyal kuat, atau mengubah media daring:

Untuk masalah jaringan internet, saya berjaga-jaga: selain menggunakan jaringan Wi-Fi di rumah, saya juga menggunakan paket data internet (SNS, 28 Juli 2020).

Untuk mengatasi kendala-kendala teknis, biasanya saya berpindah lokasi, misalnya pergi ke rumah saudara saya atau berpindah media, dari laptop ke telepon genggam (GR, 29 Juli 2020).

Untuk menemukan sinyal internet yang kuat, saya sampai naik ke atap rumah (ZT, 28 Juli 2020).

Ketersediaan jaringan internet ini pula lah yang menjadi pertimbangan mahasiswa dalam membuat keputusan apakah pulang ke kampung halaman atau tetap bertahan di kos-kosan di Surabaya. Mahasiswa berasal dari berbagai wilayah Indonesia dan beberapa di antaranya tidak memiliki jaringan internet memadai. Pengakuan mahasiswa dari Bogor dan Lampung misalnya, menyebutkan bahwa daerah mereka tidak terjangkau jaringan internet. Oleh karena itu, mereka memilih bertahan di Surabaya agar tetap dapat mengikuti perkuliahan daring.

\section{Memperbaiki Manajemen Waktu}

Manajemen waktu dan kegiatan adalah salah satu faktor yang memungkinkan mahasiswa berhasil menanggulangi berbagai tantangan perkuliahan masa pandemi:

Saya mengatur dan memanajemen waktu saya, dan mempersiapkan diri serta kesehatan (NIP, 28 Juli 2020).

Saya memanajemen waktu dan menulis list tugas. Dengan menulis list tugas, saya tambah bersemangat ketika satu persatu tugas yang ada di dalam list tercoret (ARHP, 28 Juli 2020).

Dalam menjalankan manajemen waktu dan kegiatan, subjek penelitian ini menyusun skala prioritas tugas kuliah berdasarkan bobot dan urgensi masing-masing tugas itu. Dengan demikian, mereka mencegah penumpukan beban tugas dan mengurangi stres:

Saya mengelompokkan tugas-tugas berdasarkan tingkat kesulitan dan mepetnya deadline. Saya mendahulukan tugas tersulit, mengerjakan tugas diselingi oleh hiburan, menjaga mood, dan menyelesaikan tugas sebelum deadline (NSP, 28 Juli 2020).

Membuat skala prioritas menciptakan perasaan mampu mengendalikan tugastugas dihadapi. Dengan membuat daftar tugas dan skala prioritas, mahasiswa dapat memetakan ragam tugas yang harus dikerjakan serta memantau kemajuan tugas yang dikerjakan. Pengetahuan bahwa diri telah membuat kemajuan dalam mengerjakan sesuatu dapat mengurangi stres, menciptakan rasa berdaya dan rasa kompeten.

\section{Mencari Kekurangan Materi dan Alat Penunjang Kuliah}

Akses terhadap materi kuliah merupakan salah satu persoalan yang dihadapi mahasiswa. Untuk mengatasi persoalan tersebut, mahasiswa mengerahkan dua strategi: meminjam perangkat dan meminta bantuan teman memfotokan materi:

Saya minta tolong teman saya untuk memfotokan buku mereka yang berisikan materi yang saya perlukan (DRWW, 28 Juli 2020).

Hotspot-an di kantor mama dan pinjam laptop juga (INS, 28 Juli 2020).

\section{Menegoisasikan Jadwal Perkuliahan}

Salah satu masalah yang dihadapi mahasiswa selama perkuliahan daring adalah perubahan jadwal kuliah oleh dosen. Perubahan jadwal ini cukup memberatkan dan menimbulkan ketidaknyamanan psikologis. Untuk mengatasi persoalan ini, 
mahasiswa membuat kesepakatan dengan teman-teman sekelas untuk menegosiasikan ulang jadwal pengganti perkuliahan:

Ketika dosen mengganti jadwal kuliah, teman-teman satu kelas mencoba bernegosiasi dengan dosen itu untuk memilih waktu perkuliahan di hari kerja dan pada jam kerja. Ini karena beberapa dosen memindahkan waktu perkuliahan ke hari Sabtu dan Minggu atau ke malam hari di hari-hari kerja (UST, 28 Juli 2020).

Melalui negosiasi dengan dosen, mahasiswa dapat mencegah bentrokan jadwal kuliah dan mengurangi kemungkinan dilaksanakannya perkuliahan pada waktuwaktu yang tidak nyaman.

\section{Positive Thinking, Self-Talk, Motivasi Diri}

Untuk mengurangi kecemasan dan stres dalam menghadapi beragam tantangan kuliah daring, subjek penelitian ini menggunakan self-talk:

Saya berusaha menguatkan diri dan memotivasi diri untuk segera menyelesaikan semua pekerjaan (NNFM, 28 Juli 2020).

Saya menyemangati diri agar bisa mengerjakan tugas yang menumpuk meskipun waktu luang saya tidak sebanyak biasanya (CAW, 29 Juli 2020).

Memberikan motivasi untuk diri sendiri agar tidak menyerah dan terus memberikan yang terbaik (NWA, 28 Juli 2020).

Self-talk dan motivasi diri merupakan metode yang cukup populer digunakan mahasiswa dalam menghadapi tantangan perkuliahan di masa pandemi.

Riset ini juga menyingkapkan bahwa sebagian mahasiswa menerapkan positive thinking sebagai metode kognitif dalam mengatasi berbagai problem dalam studi daring di masa COVID-19:

Mencoba tetap tenang dan berpikiran positif (S, 28 Juli 2020).
Cara saya dalam mengatasi tantangan adalah dengan selalu menanamkan pikiran positif (JNM, 28 Juli 2020).

Saya berpikir positif dan menjalankan perkuliahan daring dengan enjoy dan bertanggung jawab (SDPS, 28 Juli 2020).

Dengan berpikir positif, mahasiswa dapat mengurangi ketegangan dalam diri yang timbul sebagai akibat persoalan-persoalan perkuliahan daring.

\section{Rekreasi dan Relaksasi}

Untuk membebaskan diri dari beragam tekanan akibat mengikuti kuliah daring, mahasiswa beristirahat sejenak, berganti suasana, dan melakukan relaksasi. Ada beraneka ragam teknik relaksasi yang diterapkan, yaitu: ke luar rumah untuk berganti suasana, mengobrol dengan anggota keluarga, berolahraga dan berolah napas, makan-makan, menjalankan hobi, bermain game, mendengarkan musik, menonton film atau video YouTube, dan tidur:

Saya pergi ke laut agar merasa segar. Saya berjalan-jalan dengan sepeda motor sendirian, mengobrol dengan adik dan menelepon teman untuk mengobrol (SPAA, 29 Juli 2020).

Saya melakukan hal-hal kesukaan saya agar tidak penat, misalnya melihat video di YouTube sejenak, mendengarkan musik instrumen maupun lagu-lagu, serta melakukan peregangan otot (DKP, 28 Juli 2020).

Saya melakukan hobi saya seperti membaca buku dan belajar hal baru seperti memasak, menjahit (AS, 29 Juli 2020).

Beristirahat sejenak dengan tidur atau melakukan aktivitas yang saya sukai seperti menonton film atau membaca buku kesukaan saya (BIR, 28 Juli 2020).

Dari paparan di atas, dapat disimpulkan bahwa mahasiswa menerapkan bebe- 
rapa strategi sekaligus untuk membebaskan diri dari tekanan psikis.

\section{Religious Coping}

Riset ini menemukan bahwa sebagian mahasiswa menggunakan religious coping dalam beradaptasi pada situasi pandemi COVID-19 yang sarat tantangan:

Ketika kewalahan, saya ambil air wudhu dan sholat, untuk menenangkan pikiran yang tak keruan (NA, 28 Juli 2020).

Saya berdoa kepada Allah, memohon dilancarkan dan dikuatkan dalam situasi sulit ini (MAW, 28 Juli 2020).

Syukur

Kemampuan individu bersyukur memberikan energi positif bagi individu untuk menyikapi peristiwa-peristiwa dalam hidupnya dengan lebih efektif. Rasa syukur ini juga membantu beberapa responden penelitian ini untuk menjalani perkuliahan dengan baik di masa pandemi:

Saya menikmati kuliah [...]. Saya selalu bersyukur masih dapat belajar dari orang-orang cerdas, sedangkan di luar sana banyak teman yang ingin belajar tetapi tidak bisa karena terkendala biaya atau satu dan lain hal (H, 29 Juli 2020).

Saya menikmati apa yang saya lakukan sebab itu juga merupakan cara saya untuk bersyukur (NADY, 28 Juli 2020).

Artinya, rasa syukur atas apa yang diperoleh membantu mahasiswa menyesuaikan diri dengan perubahan drastis pada sistem perkuliahan akibat wabah COVID-19.

\section{Berbagi Cerita}

Untuk mengatasi berbagai tantangan studi di masa pandemi, beberapa mahasiswa menolong diri mereka sendiri dengan strategi coping berwujud berbagi cerita (keluh-kesah) kepada teman:

Saya berbagi cerita dengan teman-teman dan saling support secara online (RRD, 28 Juli 2020).

Saya bertukar cerita (sambat) dengan teman dekat yang juga menjalani kuliah daring (IK, 28 Juli 2020).

Berbagi cerita dengan orang dekat merupakan sarana efektif melepas stres akibat beban kuliah daring.

\section{Mencari Dukungan Sosial}

Dukungan sosial (social support) terbukti membantu meningkatkan kemampuan para mahasiswa bertahan menghadapi berbagai tantangan studi di masa pandemi:

Ketika saya stres karena terlalu banyak tugas dan materi kuliah, saya meminta tolong teman-teman untuk memberi tahu saya tugas apa yang paling mendesak (NI, 29 Juli 2020).

Saya melakukan beberapa hal, seperti mencari bantuan teman sekampus dan dari kampus lain, bekerjasama dengan teman sekelas, mengerahkan semua potensi yang ada pada keluarga, saudara, dan lingkungan kerja (DCP, 28 Juli 2020).

Dukungan sosial menciptakan rasa berdaya pada diri mahasiswa dalam menghadapi tantangan perkuliahan daring.

\section{Modifikasi Lingkungan}

Di samping bersandar pada dukungan sosial, para mahasiswa dapat survive dengan cara melakukan upaya mengubah elemen-elemen tertentu dalam lingkungan sosial mereka:

Saya meminta kedua orang tua agar ketika sedang kuliah daring, mereka tidak menyuruh saya melakukan pekerjaan rumah tangga (FAZ, 28 Juli 2020).

Saya membuat kesepakatan dengan orang rumah untuk meminimalisir ganguan (ATP, 28 Juli 2020). 


\section{Rasa Tanggung Jawab}

Dalam proses penyesuaian diri terhadap perubahan sistem belajar selama masa pandemi, rasa tanggung jawab atas pilihan sendiri merupakan faktor penting yang membantu mahasiswa menghadapi kesulitan. Mereka melakukan refleksi atas pilihan mereka dan sadar bahwa mereka bertanggungjawab atas pilihan tersebut dan siap menerima konsekuensi atas pilihannya. Meski mengalami beberapa tekanan kuliah di masa pandemi, beberapa partisipan penelitian ini mengaku menikmati kuliah di bidang ilmunya. Rasa tanggung jawab atas keputusan-keputusan yang telah dibuat secara mandiri membuat mereka mampu menyesuaikan diri dengan kondisi kuliah di masa pandemi. Berikut beberapa cuplikan data wawancara yang diperoleh:

Karena saya sendiri yang memilih jurusan ini, saya harus bertanggung jawab penuh atas pilihan saya dan menikmati suka dan dukanya (AMP, 28 Juli 2020).

Saya juga mencintai apa yang saya kerjakan dan bertanggung jawab dengan apa yang saya pilih (SMI, 28 Juli 2020).

Rasa tanggung jawab atas sebuah pilihan merupakan salah satu aspek yang membantu mahasiswa menyesuaikan diri pada perubahan pembelajaran masa pandemi.

\section{Minat dan Keingintahuan}

Terakhir, faktor yang membantu mahasiswa bertahan dalam menghadapi perubahan sistem perkuliahan yang serba tidak pasti dan penuh tekanan adalah minat, ketertarikan, dan keingintahuan mereka pada bidang ilmu yang mereka tekuni. Dari 418 mahasiswa, hanya 41 orang yang tidak me-nikmati kuliah. Alasan sebagian dari 41 mahasiswa tidak menikmati kuliah adalah karena faktor situasional pandemi.

Saya sangat menikmati kuliah, karena kuliah-kuliahnya membuat saya terpana oleh segala dinamika dalam ilmu [...].
Saya merasa penasaran dengan banyak hal dan dapat menemukan jawabannya ketika saya mempelajari ilmu [...] (NSF, 28 Juli 2020).

Saya menikmati dan menekuni mata kuliah [...]. Saya penasaran pada materimateri yang diajarkan. Saya mendapatkan ilmu yang langka. Ketika belajar dan mendapatkan penjelasan dari dosen, saya merasa kagum. Materi-materi yang diberikan aplikatif dan membantu menghadapi beberapa masalah dalam hidup (GR, 28 Juli 2020).

Bukti di atas mengarahkan pada kesimpulan bahwa walaupun sebagian besar mahasiswa tidak menikmati model belajar daring di masa pandemi, mereka mampu bertahan dalam situasi penuh tekanan karena minat dan rasa ingin tahu mereka atas materi yang mereka pelajari.

Patut dicatat bahwa dalam banyak kasus para mahasiswa menggunakan lebih dari satu metode dalam mengatasi persoalan-persoalan yang mereka hadapi. Berikut ini disajikan beberapa contoh penggunaan kombinasi metode oleh mahasiswa dalam menghadapi masalah kuliah daring:

Yang pertama saya lakukan adalah menarik napas dalam-dalam, lalu menghem-buskan napas lewat mulut pelan-pelan, kemudian berbicara pada diri sendiri: "Pelan-pelan, yuk, pasti kamu bisa. Jangan berhenti berusaha. Kamu tidak sendirian. Semua orang mengalami apa yang kamu alami. Ayo, kita sama-sama berusaha." Kadang saya banyak-banyak beristighfar biar tenang (DMP, 29 Juli 2020).

Banyak hal yang saya lakukan: masak, makan, nonton drama Korea, marah-marah, bersantai di halaman rumah, mengganggu adik. Pelarian yang paling mudah adalah makan. Kadang, saya hanya memejamkan mata di halaman rumah, menikmati angin sepoi-sepoi dan menghirup udara segar (ERNA, 28 Juli 2020).

Penerapan metode ini tergantung pada evaluasi mereka atas efektivitas metode 
yang mereka gunakan dalam mengatasi persoalan dan pengalaman mereka dalam menerapkan metode tersebut.

\section{Pembahasan}

Salah satu cara produktif untuk memaknai dampak pandemi COVID-19 atas kehidupan akademik para mahasiswa adalah dengan menaruh pengalaman mereka berkuliah daring darurat dalam konteks perkembangan mereka yang khas.

Sebagaimana pernah dipaparkan oleh Chickering (dalam Mattanah, 2016), dalam teori vektor perkembangan, sesungguhnya para subjek riset ini sedang menjalani "tujuh vektor perkembangan", yaitu: a) pengembangan kompetensi; b) manajemen emosi; c) transisi dari otonomi ke interdependensi; d) pembentukan relasi interpersonal yang matang; e) pembangunan identitas; f) penetapan tujuan hidup; dan g) pengembangan integritas. Secara teoretis, penting digarisbawahi bahwa para mahasiswa menempuh ketujuh "vektor perkembangan" itu dalam kondisi abnormal, yakni kedaruratan akademik akibat bencana pandemi virus. Temuan-temuan dalam penelitian ini menggambarkan bagaimana pandemi COVID-19 memaksa mahasiswa mengerahkan "modus darurat" dalam menempuh dua dari tujuh "vektor perkembangan" yaitu: pengelolaan emosi dan pengembangan kompetensi.

Dalam komunitas mahasiswa yang menjadi partisipan penelitian ini, manajemen emosi dan pengembangan kompetensi berkaitan erat dan timbal balik. Di satu sisi, keberhasilan dalam membangun kompetensi dapat merangsang munculnya emosi-emosi positif dalam diri mereka. Di sisi lain, efektivitas manajemen emosi ikut memengaruhi prestasi dalam penguasaan komponen teoretis, praktis dan etis dari bidang studi yang tengah mereka tekuni.

Masalahnya, dalam sejumlah cara, pandemi COVID-19 telah meningkatkan bobot kesukaran dari manajemen emosi (khususnya pencapaian dan pemeliharaan emotional well-being) pada mahasiswa subjek penelitian ini. Pertama, pandemi ini telah memukul kondisi ekonomi para orang tua dari sebagian mereka. Kedua, pandemi COVID-19 telah mengubah berbagai praktik standar dalam kehidupan sehari-hari: dari ekonomi sampai tata cara beribadah; dari mekanisme pemerintahan sampai dunia hiburan; dan dari hubungan sosial sampai tata kelola transportasi publik. Ketiga, sebagai fokus penelitian ini, aktivitas rutin belajar-mengajar telah berganti prosedur dengan cara yang mendadak dan pontang-panting, dari luring ke daring, hingga memicu terbitnya pelbagai emosi negatif dalam diri mahasiswa: bukan saja kecemasan tinggi dan rasa takut, tetapi juga disorientasi dan stres, bahkan shock dan rasa kewalahan. Hal ini selaras dengan temuan penelitian sebelumnya yang menyebutkan bahwa perkuliahan daring memicu stres dan kecemasan (Lubis \& Rasyid 2020; Andiarna \& Kusumawati, 2020;). Kalau dibiarkan lepas dari kendali, emosi-emosi negatif ini bukan saja dapat merusak kesehatan fisik dan psikis mahasiswa, tetapi juga dapat mengancam kelangsungan studi mereka.

Ancaman COVID-19 telah mengerahkan sejumlah teknik coping di bidang fisik, psikis dan akademik yang tergolong konstruktif pada mahasiswa untuk bertahan hidup. Coping konstruktif adalah beragam upaya yang sehat dan adaptif untuk mengatasi peristiwa dan kondisi yang sarat tekanan (Weiten et al., 2018). Sebagaimana ditemukan dalam riset ini, sekaligus sesuai juga dengan paparan teoretis Weiten et al., (2018), teknik-teknik coping para mahasiswa dapat kita pilah dalam tiga rumpun strategi: a) coping yang berfokus pada interpretasi; b) coping yang berpusat pada pemecahan masalah; c) coping yang berintikan manajemen emosi.

Berkenaan dengan tipe coping yang berfokus pada interpretasi (appraisalfocused coping), para mahasiswa ternyata menerapkan kombinasi dari teknik-teknik berikut ini: a) menurunkan tingkat stres dengan humor (misalnya, dengan bercanda dengan adik); b) menafsir ulang realitas 
problematik dengan menggarisbawahi aspek-aspek positifnya (misalnya, dengan menginsyafi bahwa seberat apapun tantangan yang menghadang, subjek penelitian mengakui bahwa menjadi mahasiswa adalah suatu keberuntungan, berkah, atau privilese, dan sekaligus juga sebagai sebuah "investasi" untuk karir profesional di masa depan); dan c) memaknai berbagai tekanan sebagai dampak perubahan pembelajaran di masa pandemi COVID-19 dengan menggunakan kerangka interpretasi rasional (misalnya, dengan memusatkan pikiran pada manfaat praktis, daya tarik intelektual, dan kegembiraan intrinsik dari bidang studi pilihan, dan pada rasa puas mengalami perkembangan kognitif diri sendiri).

Digunakannya canda humor sebagai teknik coping meneguhkan argumen Lefcourt (2002) bahwa humor berpotensi meringankan dampak negatif stres atas kondisi emosi. Sementara itu, penerapan reinterpretasi sebagai teknik coping mengukuhkan pengamatan Aldwin (2007) bahwa "cognitive reframing" memungkinkan manusia melakukan adaptasi positif pada situasi-situasi penuh tekanan. Akhirnya, pengerahan rasionalitas untuk mengolah realitas problematik mendukung pernyataan teoretis Ellis (2002) bahwa interpretasi irasional atas stresor dapat memicu emosi tak sehat dan, sebaliknya, tafsir rasional atas stresor dapat menggugah terbitnya emosi sehat.

Jika mempertimbangkan tipe coping yang bertumpu pada pemecahan masalah (problem-focused coping), patut dicatat laporan riset Karlsen et al. (2006) bahwa corak coping yang satu ini sudah terbukti efisien untuk mengatasi stres. Dalam konteks ini, patut dicatat bahwa para mahasiswa menggunakan tidak kurang dari tiga teknik berikut ini: a) langsung memecahkan masalah (problem-solving), misalnya menemukan koneksi internet yang stabil dan andal, tukar-menukar berbagai sumber daya pembelajaran, dan mereduksi rupa-rupa distraktor; b) mencari dan memperoleh pertolongan dari orang lain (misalnya, dari dosen, sesama mahasiswa, orang tua, kakak atau adik, dan tetangga); dan c) meningkatkan mutu manajemen waktu (utamanya dengan berbagi beban tugas rumah tangga dan menetapkan sekaligus mentaati skala prioritas untuk kegiatan sehari-hari). Temuan penelitian ini juga selaras dengan hasil penelitian Son et al. (2020) yang mengungkap bahwa mahasiswa Amerika menerapkan strategi coping melalui dukungan sosial dan manajemen diri.

Fakta bahwa sebagian subyek riset ini kadang kala berusaha memecahkan masalah secara langsung menguatkan observasi Heppner and Lee (2002) bahwa banyak studi telah menunjukkan dampak positif dari problem solving atas adaptasi psikis manusia pada tantangan-tantangan lingkungan. Selanjutnya, upaya para subjek penelitian untuk minta bantuan orang lain sebenarnya membuktikan argumen Wills (1988) bahwa teknik coping ini bertujuan untuk memperoleh beberapa tipe dukungan, yaitu dukungan informasi, dukungan motivasi, dan instrumental. Akhirnya, fakta bahwa sebagian subjek riset ini berupaya mengelola waktu mereka dengan lebih efektif menggarisbawahi pentingnya "berpikir dan bertindak jangka panjang" dalam membantu adaptasi psikis pada cepat dan kerasnya kehidupan di abad ke21 (Weiten et al., 2018).

Selaras dengan paparan teoretis dari Weiten et al. (2018) tentang gaya coping yang berfokus pada emosi (emotionfocused coping), perlu digarisbawahi bahwa para mahasiswa ternyata mengerahkan seperangkat teknik tertentu. Teknik-teknik tersebut meliputi: mencurahkan perasaan, melakukan self-talk, berbagi cerita, dan memotivasi diri; berolah raga, berekreasi, melakukan relaksasi, dan bermeditasi; dan mengembangkan rasa syukur dan melaksanakan ritual keagamaan. Fakta bahwa mereka menerapkan teknik-teknik coping ini bukanlah sebuah kebetulan. Sebab, berbagai riset empiris telah menemukan bahwa strategi coping yang berfokus pada manajemen emosi dan berbagai teknik 
tersebut terbukti membantu meningkatkan psychological adjustment manusia dalam mengatasi berbagai tantangan dalam dunia yang berubah cepat dan drastis (Emmons \& Shelton, 2002; Hofmann et al., 2010; Koenig, 2004; Sapolsky, 2004; Smyth \& Pennebaker, 1999).

Di masa pandemi, coping pada mahasiwa berinteraksi dengan dan dipengaruhi oleh coping pihak dosen. Untuk mengatasi stres mereka sendiri, sebagian dosen menggunakan teknik coping berupa manajemen waktu, yaitu dengan mengganti jadwal kuliah. Pada gilirannya, taktik ini menciptakan tekanan psikis dan fisik di pihak mahasiswa. Itu sebabnya mereka merespons dengan mengerahkan sebuah counter-coping berupa upaya bernegosiasi dengan dosen agar tidak memindahkan kuliah ke akhir pekan atau ke malam hari. Gejala ini meneguhkan argumen Aldwin (2017) bahwa coping bukan hanya proses individual tetapi juga proses kolektif, dan bahwa ketika sedang melakukan coping individual, para aktor sosial bisa bersinergi dan bisa juga berkonflik.

Setelah membahas isu-isu di atas, muncul beberapa pertanyaan yang justru dipicu oleh sebagian hasil-hasil riset ini. Pertama, apakah dan bagaimanakah kepribadian dapat memengaruhi a) interpretasi para mahasiswa atas tekanan-tekanan pembelajaran daring di masa pandemi, dan b) teknik-teknik coping yang mereka akhirnya pilih untuk menyiasati tekanan-tekanan itu. Aldwin (2007), misalnya, telah berteori bahwa kepribadian berperan penting dalam kedua hal tersebut.

Kedua, sejauh manakah tipe teknik coping yang dipilih para mahasiswa bergantung pada tipe stressor yang mereka hadapi dalam pembelajaran daring di masa pandemi? Pertanyaan ini kiranya layak diajukan, mengingat Aldwin (2007) pernah juga mengajukan klaim bahwa tipe stresor yang berbeda merangsang tipe dan proses coping yang berbeda pula.

Ketiga, apa dan bagaimana kombinasi teknik-teknik coping adaptif tertentu dapat membantu mahasiswa untuk bukan saja bertahan di masa darurat bencana (misalnya, pandemi COVID-19), tetapi juga untuk beprestasi? Secara teoretis, pertanyaan ini merujuk ke persoalan efikasi diri dari teknik coping (lihat Aldwin, 2007).

\section{Simpulan}

Berdasarkan hasil penelitian ini, dapat disimpulkan bahwa dampak negatif yang menimpa mahasiswa akibat pergantian sistem perkuliahan dari luring ke daring sebagai respon terhadap pandemi COVID-19 mencakup sejumlah masalah, yaitu: tidak stabilnya koneksi internet, menurunnya mutu kuliah yang diberikan pengajar, terhambatnya interaksi antara mahasiswa, dosen dan teman kuliah, dan terbatasnya akses ke sumber daya pembelajaran, serta terjadinya distraksi, disorientasi dan demotivasi. Dalam beradaptasi pada lingkungan pembelajaran yang penuh masalah itu, para subjek penelitian ini mengerahkan berbagai kombinasi teknik coping. Meskipun beraneka ragam, teknik-teknik coping dapat dikelompokkan ke dalam tiga gugus utama strategi, yaitu problem-focused coping, emotion-focused coping dan appraisalfocused coping. Terdapat indikasi bahwa teknik-teknik coping yang dilakukan berbagai pemangku kepentingan (mahasiswa, dosen, orang tua, dan pemerintah) bekerja secara sinergis sekaligus antagonistik.

\section{Saran}

Berdasarkan temuan penelitian ini, perlu dilakukan langkah-langkah strategis agar pembelajaran secara daring dapat berjalan lebih efektif. Dosen hendaknya menyiapkan metode yang tepat agar materi perkuliahan dapat tersampaikan dengan baik. Dengan mengingat bahwa tujuan pelaksanaan perkuliahan daring adalah untuk menjaga komunitas civitas akademik terhindar dari COVID-19, hendaknya tugas dan beban perkuliahan disesuaikan dengan kondisi pandemi. Beban tugas yang menumpuk mengakibatkan dosen mengalihkan pemberian materi dengan tugas-tugas 
mandiri. Namun, cara yang ditempuh para dosen untuk mengurangi beban tugas justru menambah beratnya tantangan penyesuaian diri pada pihak mahasiswa.

Penelitian ini juga menemukan bahwa salah satu faktor yang memengaruhi kemampuan penyesuaian diri mahasiswa dalam menghadapi tekanan akibat perubahan sistem perkuliahan adalah kepribadian. Karena itu, perlu kajian lebih lanjut bagaimana kepribadian tersebut mengubah cara mahasiswa dalam menginterpretasi tekanan akibat pembelajaran daring dan seperti apa teknik coping yang dipilihnya.

\section{Ucapan Terima Kasih}

Artikel ini disusun berdasarkan penelitian dengan pembiayaan dana penelitian kebijakan PNBP tahun 2020 dari Fakultas Ilmu Pendidikan, Universitas Negeri Surabaya, Indonesia.

\section{Daftar Pustaka}

Aldwin, C. M. (2007). Stress coping and development: An integrative perspective. Guilford Press.

Amyrah, Azmi, Oliv, \& Rika. (2020, Juni). Problematika kuliah daring: Sulitnya memahami materi dan tugas menumpuk. Lembaga Pers Mahasiswa Kompen. https://lpmkompen.com/problematik a-kuliah-daring-sulitnya-memahamimateri-dan-tugas-menumpuk/

Andiarna, F., \& Kusumawati, E. (2020). Pengaruh pembelajaran daring terhadap stres akademik mahasiswa selama pandemi Covid-19. Jurnal Psikologi, 16(2), 139-149. http://dx.doi.org/10.24014/jp.v14i2.9 221

Braun, V., \& Clarke, V. (2006). Using thematic analysis in psychology. Qualitative Research in Psychology, 3(2), $77-101$ http://dx.doi.org/10.1191/147808870 6qp063oa

Cresswell, J. W. (2012). Educational research: Planning, conducting, and evaluating quantitative and qualitative research $\left(4^{\text {th }}\right.$ ed.). Pearson.
Cresswell, J. W. (2014). Research design: Qualitative, quantitative, and mixed methods approaches. SAGE.

Ellis, A. (2002). Overcoming resistance: A rational emotive behavior therapy integrated approach ( $2^{\text {nd }}$ ed.). Springer.

Emmons, R. A., \& Shelton, C. M. (2002). Gratitude and the science of positive psychology. In C. R. Synder \& S. J. Lopez (Eds.), Handbook of positive psychology (pp. 459-471). Oxford University Press.

Firman. (2020, 13 Juni). Tantangan kuliah daring bagi dosen dan mahasiswa. Antara News. https://www.antaranews.com/berita/ 1551672/tantangan-kuliah-daringbagi-dosen-dan-mahasiswa

Harahap, A. C. P., Harahap, D. P., \& Harahap, S. R. (2020). Analisis tingkat stres akademik pada mahasiswa selama pembelajaran jarak jauh dimasa Covid-19. Biblio Couns: Jurnal Kajian Konseling dan Pendidikan, 3(1), 10-14. https://doi.org/10.30596/bibliocouns. v3i1.4804

Heppner, P. P., \& Lee, D. -G. (2002). Problem-solving appraisal and psychological adjustment. In C. R. 
Synder \& S. J. Lopez (Eds.), Handbook of positive psychology (pp. 288-298). Oxford University Press.

Hofmann, S. G., Sawyer, A. T., Witt, A. A., \& Oh, D. (2010). The effect of mindfulness-based therapy on anxiety and depression: A metaanalytical review. Journal of Consulting and Clinical Psychology, $78(2)$, $169-183$ https://doi.org/10.1037/a0018555

Hutasoit, L. (2020, 6 Mei). Hasil survei, mayoritas mahasiswa tidak suka kuliah daring: Kendala internet menjadi masalah kuliah daring. https://jogja.idntimes.com/life/educa tion/lia-hutasoit-1/89-persenmahasiswa-tidak-suka-kuliahdaring-karena-masalah-internetregional-jogja/6

Iwa, A. (2020, 23 Maret). Keluhkan kuliah daring, mahasiswa: Sebagian dosen hanya memberikan tugas. https://iainbengkulu.ac.id/index.php/ 2020/03/23/keluhkan-kuliah-daringmahasiswa-sebagian-dosen-hanyamemberikan-tugas/

Karlsen, E., Dybdahl, R., \& Vitters $\varnothing$, J. (2006). The possible benefits of difficulty: How stress can increase and decrease subjective well-being. Scandinavian Journal of Psychology, 47(5), 411-417. https://doi.org/10.1111/j.14679450.2006.00549.x

Koenig, H. (2004). Religion, spirituality, and medicine: Research findings and implications for clinical practice. South Medical Journal, 97(12), 1194-1200. https://doi.org/10.1097/01.SMJ.0000 146489.21837.CE

Lefcourt, H. M. (2002). Humor. In C. R. Synder \& S. J. Lopez (Eds.), Handbook of positive psychology (pp. 619-631). Oxford University Press.

Livana P. H, Mubin, M. F., \& Basthomi, Y. (2020). "Tugas pembelajaran" penyebab stress mahasiswa selama pandemi Covid-19. Jurnal Ilmu Keperawatan Jiwa, 3(2), 203-208. https://journal.ppnijateng.org/index. php/jikj/article/download/590/329/1 980

Lubis, H., Ramadhani, A., \& Rasyid, M. (2021). Stress akademik mahasiswa dalam melaksanakan kuliah daring selama masa Pandemi Covid 19. Psikostudia: Jurnal Psikologi, 10(1), 31-39.

https://doi.org/10.30872/psikostudia

Masriadi. (2020, 7 April). Suka duka kuliah online saat pandemi Corona: Dosen dan mahasiswa "gaptek": hingga mengeluh boros paket data. https://regional.kompas.com/read/20 20/04/07/22044941/suka-dukakuliah-online-saat-pandemi-coronadosen-dan-mahasiswagaptek?page $=$ all

Medical News Today. (2020). Coronavirus cause: Origin and how it spread. https://www.medicalnewstoday.com /articles/coronavirus-causes

Murdaningsih, D. (2020, 13 Juni). Tantangan kuliah online bagi dosen. https://republika.co.id/berita/qbv37d 368/tantangan-kuliah-online-bagidosen

Neuman, W. L. (2014). Social research methods: Qualitative and quantitative approaches ( $7^{\text {th }}$ ed.). Pearson.

Nevid, J. S., \& Rathus, S. A. (2016). Psychology and the challenges of life: Adjustment and growth. Wiley.

Nugroho, A. (2020, 19 Mei). Kuliah online pilihan tepat di saat pandemi Covid-19. https://ugm.ac.id/id/berita/19439- 
kuliah-online-pilihan-tepat-di-saatpandemi-covid-19

Panchanov, R. (2020, 28 Maret). Keluh kesah mahasiswa kuliah online, dari internet lelet hingga gagal paham. https://radarlampung.co.id/2020/03/ 28/keluh-kesah-mahasiswa-kuliahonline-dari-internet-lelet-hinggagagal-paham/

Patty, R. R. (2020, 18 Maret). Cegah Corona, Universitas Pattimura terapkan kuliah online dan ujian skripsi di ruang terbuka. https://regional.kompas.com/read/20 20/03/18/15361661/cegah-coronauniversitas-pattimura-terapkankuliah-online-dan-ujian-skripsi

Santrock, J. W. (2006). Human Adjustment. McGraw Hill.

Sapolsky, R. M. (2004). Why zebras don't get ulcers $\left(3^{\text {rd }}\right.$ ed.). Holt.

Smyth, J., \& Pennebaker, J. W. (1999). Sharing one's story: Translating emotional experiences into words as a coping tool. In C. R. Snyder (Ed.), Coping: The psychology of what works (pp. 70-89). Oxford University Press.

Son, C., Hegde, S., Smith, A., \& Wang, X. (2020). Effects of Covid-19 on college students' mental health in the United States: Interview survey study. Journal of Medical Internet Research, 22(9), 1-14. https://doi.org/10.2196/21279

Walliman, N. (2011). Research methods. Routledge.

Weiten, W., Dunn, D. S., \& Hammer, E. Y. (2015). Psychology applied to modern life: Adjustment in the 21st century $\left(11^{\text {th }} \quad\right.$ ed.). Cengage Learning.

Weiten, W., Dunn, D. S., \& Hammer, E. Y. (2018). Psychology applied to modern life: Adjustment in the 21st century $\left(12^{\text {th }} \quad\right.$ ed.). Cengage Learning.

WHO. (2020). Coronavirus disease (COVID-19) advice for the public. https://www.who.int/emergencies/di seases/novel-coronavirus2019/advice-for-public

Wills, T. A. (1988). Help-seeking as a coping mechanism. In C. R. Snyder \& C. E. Ford (Eds.), Coping with negative life events: Clinical and social psychological perspectives (pp. 19-50). Springer.

Yin, R. K. (2009). Case study research. Sage. 